\title{
Developing Needs Assessment Instrument On The Topic Of Classroom Guidance In Social Guidance And Counseling
}

\author{
Nindya Ayu Pristanti \\ Bimbingan dan Konseling, Universitas Negeri Yogyakarta \\ Email: nindya.ayu2015@student.uny.ac.id \\ Muhammad Farozin \\ Bimbingan dan Konseling, Universitas Negeri Yogyakarta \\ Email: farozin2311@gmail.com
}

(Diterima: 13-Desember-2017; di revisi: 09-Mei-2018; dipublikasikan: 27-Juni-2018)

\begin{abstract}
This study aimed to know the psychometry characteristic of need assessment instrument on the topic of classroom guidance in the social guidance and counseling services for students at SMP Negeri 1 Yogyakarta. This study was research and development followed Saifuddin Azwar model. Data collection method was a rating scale. Data analysis used content validity which was formulated by Aiken, construct validity used Exploratory Factor Analysis (EFA) and reliability analysis used Alpha Cronbach. The results of this development research were the need assessment instrument on the topic of classroom guidance in social guidance and counseling services for students at SMP N 1 Yogyakarta based on the content validity obtained 0,85, reliability 0,98 and found several new item group from exploratory factor analysis result. It could be councluded that instrument of need assessment on the topic of soscial guidance and counseling was feasible to use
\end{abstract}

Keywords: need assessment instrument, classroom guidance topic, social guidance and counseling

\section{INTRODUCTION}

Social guidance and counseling was important in the social development of junior high school students because at this time, learners steped on puberty. Early adolescence lasted from about eleven years old to fourteen years old. This period was often referred to as the transition period from childhood to adulthood. (Santrock 2003, p.42). Junior high school students who were 11-14 years old were included in the early teen category.
Based on development of adolescents specifically on socio-emotional aspects according to Santrock,, adolescents were very vulnerable to problems associated with juvenile delinquency, unwanted pregnancies, free sex, drug abuse, suicide , bullying, and brawl. then the role of teacher guidance and counseling was very great in providing preventive efforts to the learners.

In the context of personal and social life in the environment, individuals could not be separated from the process of interaction with their social environment, the social environment 
could be other individuals or social systems of society and cultural values. In the process of interaction, the individual was expected to have the skills personally and socially in order to live harmoniously with the environment.

Understanding of the interaction between himself and the social environment was needed. (Inman Sally, et al 2005: 7) said that social development concerned the topic of knowledge about self-engagement, interpersonal, social and global dimensions. The development of social skills also included interpersonal involvement and social communication skills. The topics were adapted from teenage social development tasks. Such topics could be provided through classroom guidance.

The essence of the definition of social guidance and counseling mentioned above was that social guidance and counseling was given to the individual in order to be able to face and solve his social problems and be able to develop himself in his social life. therefore, individuals could gain meaningful self and meaningful in the social environment. The aims of social guidance and counseling described above could be done with several strategies. One strategy that could be done through classroom guidance.

Previous studies conducted by Muya Barida (2016, p.27) on the Evaluation of the Implementation of Basic Social-Social Services at SMP Negeri 1 Yogyakarta stated that at the planning stage of the basic social-private service program, the counselor undertaken the needs assessment of basic personal- social by using ITP (Inventory development task) in the form of a series of statements about a condition that may occur to the respondent / student.

However, Teacher guidance and counseling experience barriers in analyzing inventory development tasks. Teacher guidance and counseling also have difficulty in developing the topic of classroom guidance services in the field of social counseling and guidance services.

Classroom guidance was part of basic services. Classroom guidance could be used as a strategy in providing social class guidance counseling and counseling services to preprogrammed learners who are composed of guidance and counseling teachers. Guidance and counseling programs were prepared based on the analysis of the need assessment. The standard types of standard need assessment tools currently available are "Alat Ungkap Masalah"
(AUM), Checklist of Problems (DCM), Developmental Task Inventories (ITP), and other developed instruments. Each instrument had their own weaknesses and advantages.

According to operational guidance of guidance and counseling in 2016 as a form of implementation of culture and education ministry rule no. 111, topic development could be based on Standards of Independence of Learners (SKKPD), purpose of area guidance and counseling service or problem area.

Innovation of this instrumen was to make the standarized need assessment instrument of classroom guidance through social guidance and counseling purposes. The instrument in question was a useful tool for assisting teachers in guidance and counseling and exploring the needs of learners on topics of classroom guidance in the social area of guidance and counseling services. Need assessment instruments were used to collect data and make decisions regarding the counselee.

Alemu (2013, p.28) developed an assessment that reveals by solving physical, emotional, social and learning problems in learners and by helping them understand their own strengths and weaknesses in learning, learners learning achievements could improve, their self-development were also increasing. Thus, assessment was very important in uncovering the needs of learners.

The instrument of need assessment on the topic of classroom guidance in the social counseling services was developed from various literatures. Both from the opinion of experts and from the regulation of the minister of education and culture no. 111 on guidance and counseling on primary and secondary education formulated into several indicators to produce topics and sub-topics. The choice of topic on the instrument was made through a literature review that not only centers on the problem, but also adapted to the social development of learners. Each service topic consisted of several subtopics. Thus, learners could choose topics that suit their needs.

The need assessment instrument was a basic tool in carrying out guidance and counseling programs. Through this instrument, Students had the potential to choose something they need. The use of this instrument in guidance and counseling services facilitated guidance and counseling teachers in developing classroom guidance in the social services area. 
Therefore, teachers in schools were required to undertake various assessment approaches to find out the needs at school (Deluca, McEwan, \& Luhang, 2016).

Assumptions in the research of the need assessment of the topic of classroom guidance services in the field of social guidance and counseling services were as follows: 1) The need assessment of the topic of classroom guidance in the field of social counseling and counseling services was feasible if in the overall developed instrument includes 2 assessments from expert guidance and counseling and teacher response counseling and counseling with good category on the face validation include the content feasibility component and the presentation of the text language.

Classroom guidance was a form of activity organized in the guidance curriculum. Classroom guidance is the part that has the largest share of guidance and counseling services, and is an efficient service, especially in addressing the problem of the ratio of the number of counselors and counselors. (Gysber and Henderson 2012, p.73).

Thus, Classroom guidance services could improve student success in school. Students had good behavior in the classroom, student attitudes became better and care about school and students could improve achievement. (Gerler and Ronald 2011, p.79).

School counselors had an influence on the development of learners that providing guidance and counseling services such as group guidance and classroom guidance. (Lapan, Gysbers and Peroski (2001, p.321). Classroom guidance was the process of providing help given to the learner in the form of face-to-face in the class on a scheduled basis with different service topics.

The equivalence of classroom counseling could be done during one semester that is considering the effective day of school where the school has 20 effective weeks in one semester. Thus, 20 weeks could be used to provide classroom guidance services in personal, social, learning and career areas. Thus, one field only gets 5 effective weeks or 5 topics delivered during an hour of subjects (40 minutes for junior high school students). Guidance and counseling teachers are expected to submit materials relating to the topics and sub topics that the student has selected.

According to operational guidance guidance and counseling guidelines, topic development on classroom guidance could be done based on students' developmental competency standards, problems, or counseling goals. Innovation is making the need assessment instrument based on social guidance and counseling objectives into topics in classroom guidance services in the field of standardized social guidance and counseling services.

Topics and subtopics would be matched to the social development task of junior high school students tailored to the purpose of social counseling and counseling, including: (1) respecting and respecting others; (2) responsible which is manifested in the form of a commitment to the task; (3) to empathize with the condition of others; (4) understanding the diversity of socio-cultural backgrounds; (5) effective social interaction; (6) resolve conflict with others on the principle of mutual benefit; (7) have the ability to make informed decisions in social situations; (8) have the ability to adjust to the values and norms prevailing in the community.

\section{METHODS}

This research used research and development approach. The subjects of the study were the students of class VII, VIII and IX of SMP Negeri 1 Yogyakarta, amounting to 10 students in the trial language and 90 students in large group trials. The steps of development according to Saifuddin Azwar include identification of measuring objectives, domain measurement constraints, aspect operations, grid creation, item writing, language testing (qualitative evaluation), field tests (large field trials), quantitative evaluation, reliability, instrument validation and final compilation. (Azwar, 2005: 15)

Expert Validation, Expert Judgment, by testing the validity of instrument need assessment by 2 experts and 3 practitioners. The validated need assessment instrument was revised as suggestion therefore the product could be used in accordance with the validator's assessment. Trials used Small group trials conducted in classes VII, VIII and IX, of which 10 students were drawn randomly as the initial field subjects to test the instrument language.

Analysis and revision of initial product, instrument need assessment has been made and tested to the students. The results of the Trials are revised in accordance with what is suggested which is used to complement the weaknesses of 
need assessment instruments. The need assessment instrument was then tested on 90 students to analyze the construct validity using exploratory factor analysis (EFA).

The data collection instrument in this study used an assessment sheet provided to expert and practitioner validators. The data in this research was obtained from rater who do assessment of instrument need assessment topic of social class guidance service field. The rater should understand and master the indicators to be assessed and understand the scale of measurements to be performed as stated in the assessment sheet.

Data analysis conducted in this study focused on testing the results of the assessors to obtain the feasibility of the need assessment instrument topic of social classroom guidance.

A measurement instrument in order to have validity had to be well constructed and include material that actually represents its measuring objective. Validity in this research consist of content validity and construct validity.

Testing the validity of the contents of the instrument need assessment of the topic of social classroom guidance material was conducted through the opinions of experts who have competence on social guidance and counseling.

The approach developed by Aiken, which has formulated the Aiken's V formula for calculating content validity coefficient based on the assessment results of the expert panel of $n$ people against an item in terms of the extent to which the aitem represents the measured constants (Azwar, 2015: 112-113) . To determine Aiken, $\mathrm{V}$ each item is formulated as follows: $\mathrm{V}=\Sigma \mathrm{s} /$ [n (c-1)] (Aiken, 1980: 956 in Saifuddin Azwar, 2015). According to the Aiken criteria table, for 5 raters, the critical value is 0.8 . If the result was below critical value, then the item needs to be fixed.

The validity of the construct shows the ability of an instrument to measure the sense contained in the material to be measured or the nature of a particular theoretical construct. Acquisition of construct validity in this research is done by exploratory factor analysis with SPSS version 20 for windows.
Determination of instrument reliability need assessment topic of social classroom guidance material was conducted by Alfa Cronbach formula using SPSS version 20 for windows.

\section{RESULTS AND DISCUSSION}

This instrument has standarized through a series of expert validation, practitioner valiadation, and field trials of users, in addition to expert validation, practitioner validation and field trials intended to obtain data as revision material.

Validation of content was obtained from the assessment of expert and practitioner validators on each item item in the instrument. The results of the content validation assessment could be seen in appendix 17. Expert validators and practitioner validators also provide an assessment of each item. Content validation was created to see matching indicators and items. The assessment was calculated using the Aiken $\mathrm{V}$ formula to determine the validity of the contents of the instrument. The content validity of the instrument is 0.85 . The validator also provided some notes for the improvement of the instrument, ie the language was more operational and the words should be adapted to the language skills of junior high school children. Calculation of content validation using aiken formula to test the accuracy of instrument need assessment topic of classroom guidance in the field of social guidance and counseling services.

$$
\begin{aligned}
\mathrm{V} & =\Sigma \mathrm{s} /[\mathrm{n}(\mathrm{c}-1)] \\
& =(1705 / 20) / 100 \\
& =0.85
\end{aligned}
$$

Based on the validity of the content, there is a value of $\mathrm{V}$ that is below the critical value. According to Aiken, for 5 people the critical value rater $\mathrm{V}$ is 0.8 . Several items were in below the critical number. Those were 20 , $21,22,26,28,31,37,39,40,41,42,51,52,55$, 99 and 100 to be considered in the improvement of the instrument. 
Tabel 1. The validity of construct

\begin{tabular}{|c|c|c|c|c|}
\hline No. & Indicator & $\begin{array}{l}\text { Component } \\
\text { Matrix }\end{array}$ & $\begin{array}{c}\text { Item } \\
\text { Accepted }\end{array}$ & $\begin{array}{l}\text { Item } \\
\text { Failed }\end{array}$ \\
\hline 1. & Respecting to others & 3 & 10 & - \\
\hline 2. & $\begin{array}{l}\text { Taking responsibility embodied in the form of } \\
\text { commitment to the task }\end{array}$ & 2 & 6 & - \\
\hline 3. & empathy on the condition of others & 2 & 4 & - \\
\hline 4. & $\begin{array}{l}\text { understanding the diversity of socio-cultural } \\
\text { backgrounds }\end{array}$ & 3 & 14 & - \\
\hline 5. & having an effective social interaction & 5 & 18 & - \\
\hline 6. & having the ability to solve conflicts & 2 & 8 & - \\
\hline 7. & $\begin{array}{l}\text { having the ability to make decisions within the } \\
\text { social context }\end{array}$ & 2 & 8 & - \\
\hline 8. & $\begin{array}{l}\text { having the ability to adjust the values and norms } \\
\text { in society }\end{array}$ & 6 & 28 & 2 \\
\hline
\end{tabular}

The validity of the construct was carried out in large groups after revising the need assessment instrument on the topic of classroom guidance in the area of counseling and social counseling services based on comments and suggestions from small group trials. Filling the need assessment instrument on the topic of classroom guidance in the field of social guidance and counseling services was held at SMP Negeri 1 Yogyakarta class VII, VIII and IX with the number of 90 students.

The results of this large group trial measured the need assessment instrument construct of the topic of classroom guidance in the field of social guidance and counseling services with Exploratory Factor Analysis (EFA) The result of construct validity is that there are several matrix components The matrix component was the grouping of items in the new indicator of exploratory factor analysis .

In the first indicator, respecting others was obtained 3 components of the matrix are: 1) have a good respect and moral attitude toward parents and teachers; 2) respect peers; 3) apply the attitude and behavior of respect in daily life. In the first indicator, there are 10 items received and no items fall.

The second indicator, which had responsibilities embodied in the form of commitment to the task, obtained 2 components of the matrix, namely: 1) recognize the characteristics of responsible individuals; and 2) had an attitude of responsibility in the group task. There are 6 items accepted so there are no items to fall.

In the third indicator, empathy on the condition of others obtained 2 components of the matrix that was 1) empathy at friends and 2) helping others. There are 4 items accepted so there are no items to fall.

In the fourth indicator, understanding the diversity of socio-cultural backgrounds obtained 3 components of the matrix are: 1) have the attitude of tolerance to differences in religion, culture and nation; 2) the importance of tolerance, and 3) knowing the nature of women and men. There are 14 items received and no items are missing.

In the fifth indicator, having an effective social interaction, the matrix component is obtained: 1) understanding the importance of interacting with others 2) being a good listener; 3) Maintaining relationships among individuals; 4) implementing effective means of communication; and 5) communication between individuals. There were 15 items received and 3 items fall.

In the sixth indicator, having the ability to solve conflicts, two matrix components were obtained, 1) knowing how to resolve the conflict, and 2) knowing the importance of working together in resolving the conflict. There are 8 items accepted therefore, no items was dropped.

In the seventh indicator, having the ability to make decisions within the social sphere, two matrix components were obtained: 1) understanding how to make decisions in the social sphere, and 2) applying ways to solve a good problem. There were 8 items accepted, therefore no items were dropped.

Finally on the eighth indicator, having the ability to adjust to the values and norms prevailing in society, obtained 6 components of 
the matrix, namely 1) understanding the dangers of juvenile delinquency; 2) recognize good behavior in life; 3) Have a good life principle; 4) know the rules that apply in the community environment; 5) bullying on social media; 6) understand the effort to adjust to the values and norms in society. There are 28 items received and 2 items fall. Item drops because the value (value) in the pattern matrix does not reach 0.4.

The reliability of need assessment instrument classroom guidance topics in the field of social guidance and counseling services based on the assessment of some experts and practically analyzed using Alfa Cronbach formula through SPSS version 20 for windows is 0.98 .

Based on the results of validity and reliability of the instrument, it could be said that this instrument was standardized and could be used in analyzing the needs of learners on the topic of classroom guidance in the field of social guidance and counseling services. By utilizing this instrument, guidance and counseling teachers could capture student data in determining the topics that were most prioritized.

This need assessment instrument was an appropriate instrument for establishing guidance and counseling programs on the classroom guidance of social guidance and counseling services. This is based on the theory of Saifuddin Azwar (2015: 15) that a good instrument was an instrument that had through the steps of the development of the instrument and had been tested for its validity and reliability, therefore its psychometric characteristics have been met.

The need assessment instrument could be said appropriate in analyzing student needs (Dogar, A.H., et al, 2011). Dogar said that the need assessment instrument that has been tested for validity and reliability was appropriate and could be used in analyzing the needs of students in the school, need assessment instruments could be done to mengataahui topics that students need in classroom guidance services in the field of social guidance and counseling services.

The need assessment instrument of the topic of classroom guidance in the field of social guidance and counseling services is complemented by manuals to facilitate guidance and counseling teachers in analyzing the need assessment instruments on the topic of classroom guidance in the field of social guidance and counseling services.
The results of this study could add contributions in guidance and counseling, especially in the field of social guidance and counseling services. Teacher guidance and counseling could utilize instrument of this standard as a tool to do need assessment of learners in effort of giving classroom guidance in social counseling service and counseling so that learners could choose topic based on requirement level according to their social development task.

\section{CONCLUSION}

The need assessment instrument on the topic of classroom guidance in the field of social counseling and services was appropriate to be used on the basis of expert judgment with average content validity of 0.85 and reliability of 0.98 .

Teacher guidance and counseling could use this instrument as a new innovation in doing need assessment to students. This instrument could facilitate teacher guidance and counseling in capturing the needs of students to the classroom guidance services provided in the semester program or annual program.

The researcher could then develop a need assessment instrument based on the computerized system in analyzing the data, and could develop topics of classroom guidance in the field of further guidance and counseling services into a book that could be delivered to the classroom guidance services in the field of social counseling and guidance services

\section{REFERENCES}

Alemu, Y. (2013). Assessment of the provisions of guidance and counseling services in secondary schoos of East Harerge Zone and Hareri Region, Ethiopia. Middle Eastern \& Africould Journal of Educational Research, Issues 2, 28-37.

Deluca, C., LaPointe-McEwan, D. \& Luhang, U. (2016). Approaches to classroom assessment inventory: A new instrument to support teacehar assessment literacy. Educational Assessment, 21, 248-266.

Dogar, A. H., Azeem, M., Majoka,M. I., et al. (2011). Need assessment of students' guidance and counseling. British Journal of Arts and Social Sciences, 1, 2, 108-124. 
Pristanti, Farozin., Developing needs asessment... $\mid 53$

Gerler, Edwin R dan Ronald F. Anderson. (2011). The effect of classroom guidance on children's success in school. journal of counseling and development. Volume 65. Issue 2. Hal 78-82.

Gysbers, Norman C. (2012). Developing and managing: Your school guidance and counseling program. Alexandria. Americould Counseling Association.

Lapan, R. T., Gysbers, N. C, \& Peroski, G. F. (2001). Helping seventh graders be safe and successful: A statewide study of the impact of comprehensive guidance and counseling programs. Journal of Counseling and Development 79, 320330.

Muya Barida. (2016). Evaluasi pelaksanaan layanan dasar bidang pribadi-sosial di SMP Negeri 1 Yogyakarta. Jurnal Fokus Konseling. 1, 21-31.

Saifuddin Azwar. (2015). Penyusunan skala psikologi. Yogyakarta: Pustaka Pelajar

Santrock, J.W. (2003). Adolescence:

Perkembangan remaja. (Terjemahan: Shinto B. Adelar dan Sherly Saragih). Jakarta: Erlangga. 